\title{
EFFECTIVE FORMATIVE ASSESSMENT STRATEGIES CONTRIBUTE POSITIVELY TO THE WORK-READINESS OF NEW GRADUATES IN HIGHER EDUCATION
}

\author{
Tara Malone
}

\section{INTRODUCTION}

Assessment has long been viewed as central to the student's experience; historically, pedagogy demonstrated that teachers teach to the test, students learn for the test, and curriculum is often designed to support and guide both functions. Assessment defines what students view as being important, with a focus often placed on assessment preparation as opposed to class attendance (Gibbs 2007a, cited in Price et al., 201 I). Student outcomes were mainly viewed as being related to intellect and effort, rather than the need for institutions to cater to the student's individual needs (Wiliam, 20I I). Assessment was not even considered to be a part of the learning process (Pla-Campas et al., 2016); rather, it was something 'done' to students at the end of instruction. While Gipps (1994, as cited in Lau, 2016) proposed a complete shift from the intellectual model to the cognitive model, Lau (2016) suggests that studies by Biggs (1998) and Taras (2005) demonstrate the need for a balance: that summative and formative assessment should be connected to each other, to the teaching and learning environment, and to the student.

This article explores current understanding and practices of assessment in the tertiary education sector, and the implications for practice that sustainable assessment has in equipping students to meet the demands of the real world.

\section{LIFELONG LEARNING IN A CHANGING SOCIETY}

Interest in teaching and learning practices across higher levels of education point to the need for a shift from passive learning to an active learning model (Boud \& Falchikov, 2006), as part of a student-centred approach. Active learning results in students attaining deep learning and understanding, being responsible and accountable for their learning, being autonomous and having an interdependent, rather than dependent, relationship with the teacher (Lea et al., 2003). Literature supports this shift as graduates encounter a competitive market where there is a demand for lifelong learners (Fook \& Sidhu, 2013) who can meet the changing economic and sociocultural demands of society. These demands include being work-ready, having the ability to think critically, being innovative, creative and future-oriented (Ministry of Science, Technology and Innovation, 2005, cited in Gerritsen-van Leeuwenkamp et al., 2017).

To cite healthcare as an example of these work-ready requirements of industry, new graduates will possess leadership skills, are self-aware (Allen et al., 2009) and are competent communicators and collaborators (Nursing Council of New Zealand [NCNZ], 2015). Furthermore, new graduate nurses are expected to be competent in exercising their professional responsibilities and management of nursing care, and have the ability to form and sustain interpersonal and inter-professional relationships (New Zealand Nursing Council [NZNC], 2007). The 
literature suggests that sustainable assessment, which focuses on equipping students with skills for success in future assessment tasks, as well as tasks in the 'here and now,' is an effective strategy towards achieving work-readiness (Boud \& Soler, 2016).

\section{ASSESSMENT AND LEARNING}

Summative assessment, also referred to as assessment of learning, occurs after learning has taken place, and is designed to assess if students have learned what they were supposed to have learned (Tang \& Biggs, 2007; Sadler \& Reimann, 20I8; Taylor \& Burke da Silva, 2014). These assessments are generally viewed as high-stakes assessment, with the grade contributing to overall success, or failure, for the student (Yorke, 2003). Formative assessment, however, defined as assessment for learning (Black, 1986, cited in Wiliam, 20II), takes place during the learning (Cowie \& Bell, 1999, cited in Wiliam, 20II; Sadler \& Reimann, 2018; Taylor \& Burke da Silva, 2014), occurring within a partnership between teacher and student, with the purpose of enhancing the student's abilities to their fullest potential (Yorke, 2003).

Learning can be considered as a process whereby the student consistently constructs their knowledge, rather than reproducing knowledge (Barr \& Tagg, 1995, DeCorte, 1996, Nicol, 1997, cited in Nicol \& MacFarlane, 2006), with both surface and deep learning occurring not as the result of personality traits, but rather, of the teaching and learning environment (Biggs, 2012). There is a call for assessment practices to align with this thinking (Boud, 2000, cited in Boud \& Falchikov, 2006). Ensuring robust formative assessment processes, which have the ability to provide students with feedback on their learning, during their learning, leads to improved results for students in higher education settings (Hattie \& Timperley 2007; López-Pastor et al., 2013, cited in López-Pastor \& SiciliaCamacho, 2017). This includes empowering them to become self-regulated learners (Carless, 2006, cited in Sadler, 2010). Continuous and qualitative feedback, and peer- and self-assessment as part of the formative assessment process, are also aspects of a student-centred approach to learning (Lea et al., 2003) and development of the student's knowledge of self.

Tang \& Biggs, (2007) view effective learning as that which reframes our worldview; this occurs through how we think about the knowledge we acquire, rather than just the acquisition of knowledge. Because higher education is the last systematic stage of education, whereby the student can widen their perspective in preparation for life (Boud \& Falchikov, 2006), it is important that student outcomes are maximised. To understand this point further in relation to work-readiness, the purpose and current practice of formative assessment in the higher education setting, as part of sustainable assessment (Boud \& Soler, 2016), is investigated below.

\section{HIGHER EDUCATION AND ASSESSMENT}

Internationally, the Bologna Declaration of 1999 (cited in Pereira et al., 2016) started a rethink of assessment processes, launching a move towards a student-centric approach to teaching and learning, where students are viewed as active learners, able to participate in their own learning, and are critical thinkers. This meant a move towards assessment processes that developed student autonomy and self-responsibility for learning, including the practice of self-reflection as a means of reviewing their own learning (Sluijsmans et al., 1999, cited in Pereira et al., 2016).

Providers of higher education are judged on the quality of their graduates; assessment practices determine this quality (Boud, 2017). Hence, students focus their learning around assessment. Brown and Knight (1994) confirm this premise by stating that "assessment is at the heart of the student experience" (cited in Price et al., 20II), and it is assessment information and outcomes that determine the student's ability to meet the societal demands placed on today's graduates. Although support for formative assessment processes in higher education is growing, there remains a professional culture that associates assessment solely with final grades and examinations (Zabalza, 2003, 
cited in López-Pastor \& Sicilia-Camacho, 2017). Boud (2017) describes assessment as having three main functions: firstly, to verify student performance; secondly, to provide feedback to aid further learning; and thirdly, to build the student's capacity to make decisions about their own learning. Sustainable assessment allows the student to utilise feedback to move forward, not only contributing to what is being learned in the classroom, but also deepening the learning and evaluative skills required for lifelong learning and successful employment (Bloxham \& Boyd, 2007; Segers \& Dochy, 200I, cited in Pereira et al., 2016).

The move towards a more student-centred, continuous form of assessment practice also promotes the use of group and peer work (Bloxham \& Boyd, 2007, cited in MacFarlane, 2016) - again, skills relevant for employment. It is therefore reasonable to conclude that while summative assessment determines what the new graduate should know, formative assessment contributes more to developing the new graduate to be prepared for further societal demands. Additional influences can be traced to the rise of the student engagement movement (MacFarlane, 2016), which led to higher education facilities thinking creatively about how to better engage and retain students; assessment is itself an opportunity for student engagement. Furthermore, assessment should contribute to the principal objective of higher education: to develop students' capacity and enable them to be independent, self-critical learners, having the ability to evaluate and act on the need for improvement (Ion et al., 2017).

Today, assessment is evolving, with a shift in focus from summative assessment towards a more blended approach to teaching and learning (Sadler \& Reimann, 2018); often summative and formative approaches are used concurrently. Historically, the focus of higher education was on producing small, elitist groups of intellectuals (Pryor \& Crossouard, 2010); conventional summative assessment models measured this intellectual quantum by setting tests which measured skills, knowledge and attitudes towards goals set by teachers (Gipps, 20I2, as cited in Sadler \& Reimann, 2018). The student role was passive and there was little interaction between teacher and student (Schuwirth \& Van der Vleuten, 20II; Shepard, 2000, cited in Gerritsen-van Leeuwenkamp et al., 2017). Assessment was informed by trait theory, whereby a student's intelligence and abilities were predetermined, based on their genetic makeup, and were innate and fixed (Taylor, 1994; Gipps, 1994; Hager \& Butler, 1996, cited in Lau, 2016).

A shift from focussing on intelligence to cognition meant that the process of thinking, reasoning and interaction with others led to a new way of considering assessment (Shepard, 2000, cited in Lau, 2016). Universities and other tertiary education providers are now required to cater for a wide range of diverse individuals, who are creative thinkers competing globally for employment opportunities (Pryor \& Crossouard, 2010). A review of the literature undertaken by Pereira et al. in 2016 suggests that assessment methods in higher education, other than conventional tests, benefit students learning, including the interpersonal relationship between student and teacher. While assessment does need to measure achievement and provide quality assurance and accountability for higher education facilities, it also needs to enhance learning by engaging, motivating and stimulating students, as well as providing robust feedback (Price et al., 201I).

Research shows that formative assessment impacts positively on students' learning and final grades (Fisher et al., 20II; Romero-Martín et al., 2014, cited in Pla-Campus et al., 2016). Formative assessment gives the student the chance to examine their own learning (Nicol \& Macfarlane-Dick, 2006); using effective formative assessment practices in higher education settings could be the link between learning and the development of work-ready skills and attributes. The major elements of formative assessment, as outlined by Wiliam (201 I), are the provision of effective feedback; the active involvement of students in their own learning; consideration of assessment results in teaching practices; recognition of the effect assessment has on motivation and self-esteem; the need for self-assessment; and an understanding of how to improve (Wiliam, 20lI). Good formative assessment processes involve the active partnership between teacher and student to enable the best performance by the student (Rushton, 2005; Windstone \& Boud, 2018). Self-regulating the learning process is part of the student learning to learn (James, 2015, cited in Lysaght, 2015; Senye-Mir et al., 2016). 
Formative assessment processes, in particular feedback, are viewed as the most powerful enhancer of learning (Hattie, 1987, cited in Rushton, 2005; Tang \& Biggs, 2007; Hattie \& Timperley, 2007). However, research and student satisfaction surveys reveal that feedback is often lacking in both quality and quantity, leading to frustration and disengagement (Price et al., 20II; Taylor \& Burke da Silva, 2014; Windstone \& Boud, 2018). Thus, there is an onus on higher education facilities to improve practice. By learning to understand what is expected of them to meet learning outcomes, students, through feedback, learn to self-regulate (Yorke, 2003). In the higher education context, self-regulation leads to the student's empowerment through monitoring and regulation of their own learning of both internal and external goals (Nicol \& Macfarlane-Dick, 2006). Students with a higher level of self-regulation make better use of internal and external feedback (Nicol \& Macfarlane-Dick, 2006), and can better regulate aspects of their thinking, motivation and behaviours during their learning (Pintrich \& Zusho, 2002, cited in Nicol \& Macfarlane-Dick, 2006), in preparation for skills required following graduation (Boud, 2000). The ability to self-evaluate is therefore integral to learning (Rushton, 2005), especially where deep learning is concerned.

Further to this is the need to align assessment practices with lifelong learning, as the skills and attributes required of new graduates will evolve further in the near future (Boud \& Falchikov, 2006). Students who are lifelong learners will be more able to adapt to continually meet these changing demands; Boud and Falchikov (2006) suggest that sustainable assessment (Boud \& Soler, 2016), in particular the processes involved in formative assessment, can contribute to the development of lifelong learning skills.

\section{CONSIDERATIONS AND IMPLICATIONS FOR PRACTICE}

Sadler (1989, cited in Fook \& Sidhu, 2013) views formative assessment as a tool to give teachers information that improves teaching, a tool which should be utilised to help students understand how they learn best and how well they have learned. Formative assessment also enables the planning of individual teaching strategies, the provision of useful and effective feedback, and gives rise to opportunities for students to reach their potential and assess their own learning efficiently (Sadler, 1989, cited in Fook \& Sidhu, 2013). In essence, formative assessment is a tool that develops students into self-regulated graduates (Nicol \& MacFarlane-Dick, 2006), who are ready to succeed and meet the demands of society. Given the well-documented importance of feedback, it is concerning that the literature identifies the giving of feedback, and feedforward, as one of the weakest assessment processes (Carless et al., 20II; Pereira et al., 2008; Price et al., 20I0; Scoles et al., 2012, cited in O'Donovan et al., 2016; Taylor \& Burke da Silva, 2014). There are, however, some barriers to the successful use of formative assessment in higher education that need to be considered, and room for the development of new and innovative practices.

There is a dearth of empirical literature that explores teachers' understanding of formative and summative models of assessment (Sadler \& Reimann, 2018). However, Maclellan (200I) undertook a study which demonstrated that while staff had an awareness of and commitment to undertaking formative assessment, many of their practices did not correlate with demonstrating this, with the emphasis being placed on grading as opposed to students' motivation for learning. It can therefore be assumed that student learning, through the use of formative assessment, is largely dependent on the teacher's engagement with formative assessment (Koh, 2009). Additional to this are the teacher's personal values and beliefs about teaching and learning practices (Samuelowicz \& Bain, 2002, cited in Koh, 2009). Furthermore, a study by Lysaght in 2015 found that teachers overestimated their understanding and use of formative assessment processes, and were reluctant to explore them further for fear of undermining the quality of their existing teaching, learning and assessment practices.

Cowie and Bell (1999, cited in Yorke, 2003) found that in the secondary school setting, teachers sometimes did not recognise when they were undertaking formative assessment activities, and so opportunities were often missed; this may be true also of higher education. In addition, pressure is often placed on teachers in higher education to direct their attention to summative assessment, which provides institutions with information with which to measure the demands of accountability, outcomes and quality assurance, leaving little time to focus on how the student actually learns. Practice, therefore, continues to focus on teaching to the test (Lau, 2016). 
While Falchikov and Boud (2007, cited in Rowe 20II) acknowledge the potential for the generation of strong feelings attached to assessment, Rowe (20II) investigated the link between emotions and students' response to assessment and feedback in higher education. It is known that positive emotions - and sometimes negative ones - enhance learning, particularly self-regulation and motivation (Pekrun \& Stephens, 2010, cited in Rowe, 2017), attributes identified in this article as work-ready skills.

Feedback has the potential to elicit emotion in both teacher and student. According to Rowe (2017), emphasis should be placed on the importance of teachers understanding their students, which may be enhanced through relationships and teaching strategies. However, the teacher's ability to engage in this process is often hindered by their understanding of assessment practices (Sadler \& Reimann, 2018), academic workloads (Taylor \& Burke da Silva, 20I4), and feelings of inadequacy in their ability to deal with emotions (Rowe, 2017). A more student-centred approach, in line with developing real-world skills, involves enhancement of the student's ability to self-manage and better utilise their emotions (Rowe, 2013, cited in Rowe, 2017). Evans (2013) also emphasises the need to acknowledge the affective component of giving and receiving feedback, particularly the connection between emotions, cognitive and conative processes and, indeed, resiliency (Rowe, 2017).

Strategies such as e-assessment feedback, via a variety of digital technologies, allow opportunities for effective feedback in large cohorts (Gikandi et al., 20II, cited in Evans, 2013). There is a positive impact on student outcomes through the use of feedback experiences that are relevant to students of this generation of "digital natives" (Gilbert et al., 200I, cited in Evans, 2013). However, emphasis needs to be placed on the training and instruction given to students, and teachers, for this type of feedback to be effective (Evans, 2013). Podcasts, as tools for feedback, also need to be considered, given their potential to promote efficacy in both individuals and groups (McSwiggan \& Campbell, 2016). Other strategies include the use of clickers in large lecture situations (Ludvigsen et al., 20I5) and online games, discussed by Broussard (2012), as innovative ways to formatively assess.

Formative assessment and game-based learning share seven common aims: to promote active learning environments; support the use of frequent and immediate feedback; provide intrinsic motivation; allow opportunities to practice and test knowledge without consequence; support scaffolded learning; encourage reflection and problem-based critical thinking; and provide opportunities for social learning. Other tools for assessment and learning, such as portfolios, have been found to enhance self-regulation and development of learning skills, and e-portfolios have the ability to provide timely feedback to the student (Beishuizen et al., 2006).

Although Nicol (2009) posits that the student enters higher education with the ability to self-regulate, Alkaher and Dolan (20II, cited in Evans, 2013) suggest that all students need assistance with aspects of self-regulation to benefit their learning. To enable students and teachers to ascertain what that assistance is, they firstly need to understand the student's ability to make judgements about their learning, and strategies used to develop learning (Lew et al., 2010, cited in Evans, 2013). Weurlander, et al., (2012) found that continuous formative assessment opportunities impacted on students' success by making them aware of their own learning and their contribution to that learning; however, consideration needs to be given to student workload and creativity in planning assessments. These findings are supported by a study undertaken by Hernandez (2012). Rowe (201I, cited in Ekholm et al., 2015) suggests that in higher education settings, the student's perception of feedback is especially important; given the often-large cohorts involved, this may be the sole source of relationship with the teacher.

\section{CONCLUSION}

While formative and summative assessment both have merit in the higher education setting, there needs to be a balance. Measuring what the student knows in order to meet the increasing demands for (both internal and external) institutional credibility, accountability, retention, completion, and quality assurance cannot usurp the importance of providing equality and equity for a diverse range of lifelong learners to reach their fullest potential. Graduates need to be adequately prepared to meet the global economic and societal real-world demands that 
they face. This article highlights how formative assessment can be used as an effective strategy to promote self-regulation and the graduate's preparation for the real world, but there is considerable work to be undertaken to ensure that students and teachers have a clear understanding of what formative assessment entails.

The literature supports the hypothesis that formative assessment can contribute to the work-readiness of new graduates in higher education by encouraging deep learning and fostering a lifelong learning approach; developing the student's ability to self-regulate, self-reflect and attain self-efficacy; and generating opportunities to enhance interpersonal skills through teacher-student relationships. Being work-ready means having the ability to think critically, be innovative, creative and future-oriented (Ministry of Science, Technology and Innovation, 2005, cited in Gerritsen-van Leeuwenkamp et al., 2017), be a competent communicator, possess leadership skills and be self-aware (Allen et al., 2009). Effective, informed and purposeful feedback, feedforward and self-assessment are valid processes to enable this to happen.

It is impossible to ensure that higher education is moving in the right direction without considering the view through both the teacher's and student's lens. However, there seems to be an inconsistency in the literature between teacher and student perceptions (Windstone \& Boud, 20I4), in addition to the value placed on the role of formative assessment in enhancing real-life skills and the student's knowledge and awareness of this value - two areas for further investigation. Students (and teachers) need to value feedback and feedforward as a way of enhancing their learning (Mulliner \& Tucker, 2017), not just something received following an assessment. Thus, higher education facilities need to develop a culture that is inclusive of, and values, formative assessment as an effective learning tool (Havnes et al., 20I2). If graduates need to be future-focussed, critical thinkers, selfregulators, motivated, innovative, resilient and creative to compete in the real world, so too, then, do higher education facilities and their assessment practices.

Tara Malone is a registered nurse with a specialty in mental health. She has worked as a nurse lecturer at Te Kura Matatini o Taranaki for nine years, is currently completing a MEd, and is passionate about developing strategies to identify and overcome barriers to success for students in higher education.

(10) https://orcid.org/0000-0003-4040-3819

\section{REFERENCES}

Allen, D. E., Ploeg, J., \& Kaasalainen, S. (2012). The Relationship Between Emotional Intelligence and Clinical Teaching Effectiveness in Nursing Faculty. Journal of Professional Nursing, 28(4), 231-240. https://doi.org/l0.1016/j.profnurs.2011.11.018

Beishuizen, J., Van Boxel, P., Banyard, P., Twiner, A., Vermeij, H., \& Underwood, J. (2006). The introduction of portfolios in higher education: A comparative study in the UK and the Netherlands. European Journal of Education, 4I(3/4), 49I-509.

Biggs, J. (1998). Assessment and Classroom Learning: a role for summative assessment? Assessment in Education: Principles, Policy \& Practice, 5(I), 103-II0. https://doi.org/10.1080/0969595980050106

Biggs, J. (20I2). What the student does: teaching for enhanced learning. Higher Education Research and Development, 3I (I), 39-55. https://doi.org/10.1080/07294360.2012.64283

Bloxham, S., \& Boyd, P. (2007). The evidence base for assessment practice in higher education. In S. Bloxham \& P. Boyd (Eds.), Developing effective assessment in higher education: A practical guide (pp. 15-31). McGraw-Hill Education.

Boud, D. (2000). Sustainable assessment: Rethinking assessment for the learning society. Studies in Continuing Education, 22(2), $15 \mid-167$.

Boud, D. (2017). Standards-based assessment for an era of increasing transparency. In D. Carless, S. Bridges, C. Chan, \& R. Glofcheski (Eds.), Scaling up Assessment for Learning in Higher Education: The Enabling Power of Assessment, 5 (pp. 19-31). Springer. 
Boud, D., \& Falchikov, N. (2006). Aligning assessment with long-term learning. Assessment \& Evaluation in Higher Education, 31 (4), 399-413.

Boud, D., \& Soler, R. (2016). Sustainable assessment revisited. Assessment \& Evaluation in Higher Education, 4I(3), 400-413. https://doi.org/10.1080/02602938.2015.1018133

Broussard, M. (2014). Using games to make formative assessment fun in the academic library. The Journal of Academic Librarianship, $40(1), 35-42$.

Carless, D. (20II). From testing to productive student learning: implementing formative assessment in confucian-heritage settings. Routledge.

Ekholm, E., Zumbrunn, S., \& Conklin, S. (2015). The relation of college student self-efficacy toward writing and writing selfregulation aptitude: writing feedback perceptions as a mediating variable. Teaching in Higher Education, 20(2), $197-207$. https://doi.org/l0.1080/135625/7.2014.974026

Evans, C. (2013). Making sense of assessment feedback in higher education. Review of Educational Research, 83(I), 70-120.

Fisher, R., Cavanagh, J., \& Bowles, A. (20II). Assisting transition to university: using assessment as a formative learning tool. Assessment and Evaluation in Higher Education, 36(2), 225-237. https://doi.org/l 0.1080/02602930903308241

Fook, C. Y., \& Sidhu, G. K. (2013). Learning Practices in a Higher Learning Institute in United States. Procedia, Social and Behavioral Sciences, 90, 88-97. https://doi.org/10.1016/j.sbspro.2013.07.069

Gerritsen-van Leeuwenkamp, K. J., Joosten-ten Brinke, D., \& Kester, L. (2017). Assessment quality in tertiary education: an integrative literature review. Studies in Educational Evaluation, 55, 94-

Gipps, C. (1994). Developments in Educational Assessment: what makes a good test? Assessment in Education: Principles, Policy \& Practice, I(3), 283-292. https://doi.org/l0.1080/0969594940010304

Hattie, J., \& Timperley, H. (2007). The power of feedback. Review of Educational Research, 77(I), 81-1I2.

Havnes, A., Smith, K., Dysthe, O., \& Ludvigsen, K. (2012). Formative assessment and feedback: Making learning visible. Studies in Educational Evaluation, 38(I), 21-27.

Hernandez, R. (2012). Does continuous assessment in higher education support student learning? Higher Education: The International Journal of Higher Education and Educational Planning, 64(4), 489-502.

Ion, G., Cano-García, E., \& Fernández-Ferrer, M. (2017). Enhancing self-regulated learning through using written feedback in higher education. International Journal of Educational Research, 85, I-10. https://doi.org/l0.1016/j.ijer.2017.06.002

Koh, L. (2010). Academic staff perspectives of formative assessment in nurse education. Nurse Education in Practice, 10(4), 205-209.

Lau, A. M. S. (2016). "Formative good, summative bad?" - A review of the dichotomy in assessment literature. Journal of Further and Higher Education, 40(4), 509-525. https://doi.org/l0.1080/0309877X.2014.984600

Lea, S. J., Stephenson, D., \& Troy, J. (2003). Higher Education Students' Attitudes to Student-centred Learning: Beyond "educational bulimia"? Studies in Higher Education (Dorchester-on-Thames), 28(3), 32I-334. https://doi.org/l0. 1080/03075070309293

López-Pastor, V., \& Sicilia-Camacho, A. (2017). Formative and shared assessment in higher education. Lessons learned and challenges for the future. Assessment \& Evaluation in Higher Education, 42(1), 77-97.

Ludvigsen, K., Krumsvik, R., \& Furnes, B. (2015). Creating formative feedback spaces in large lectures. Computers \& Education, 88, 48-63.

Lysaght, Z. (2015). Assessment for learning and for self-regulation. International Journal of Emotional Education, 7(I), 20-34.

Macfarlane, B. (2016). The performative turn in the assessment of student learning: A rights perspective. Teaching in Higher Education, 21(7), 839-853.

Maclellan, E. (200I). Assessment for learning: The differing perceptions of tutors and students. Assessment \& Evaluation in Higher Education, 26(4), 307-318.

McSwiggan, L., \& Campbell, M. (2017). Can podcasts for assessment guidance and feedback promote self-efficacy among undergraduate nursing students? A qualitative study. Nurse Education Today, 49, 115-121.

Mulliner, E., \& Tucker, M. (2017). Feedback on feedback practice: Perceptions of students and academics. Assessment \& Evaluation in Higher Education, 42(2), 266-288.

New Zealand Nursing Council. (2007). Competencies for registered nurses. https://www.nursingcouncil.org.nz/NCNZ/nursingsection/Registered_nurse.aspx

New Zealand Nursing Council. (2015). Education programme standards for the registered nurse scope of practice. http://www. nursingcouncil.org.nz/content/download/33I/I54I/file/Education\%20Programme\%20Standards\%20AprI5.doc

Nicol, D. (2009). Assessment for learner self-regulation: Enhancing achievement in the first year using learning technologies. Assessment \& Evaluation in Higher Education, 34(3), 335-352. 
Nicol, D. \& Macfarlane-Dick, D. (2006). Formative assessment and self-regulated learning: A model and seven principles of good feedback practice. Studies in Higher Education, 31(2), 199-218.

O'Donovan, B., Rust, C., \& Price, M. (2016). A scholarly approach to solving the feedback dilemma in practice. Assessment \& Evaluation in Higher Education, 4I(6), 938-949.

Pereira, D., Flores, A., \& Niklasson, L. (2016). Assessment revisited: A review of research in assessment and evaluation in higher education. Assessment \& Evaluation in Higher Education, 4I(7), 1008-1032.

Pla-Campas, G., Arumí-Prat, J., Senye-Mir, A., \& Ramírez, E. (2016). Effect of using formative assessment techniques on students' grades. Procedia - Social and Behavioral Sciences, 228, 190-195.

Price, M., Carroll, J., O'Donovan, B., \& Rust, C. (20II). If I was going there I wouldn't start from here: A critical commentary on current assessment practice. Assessment \& Evaluation in Higher Education, 36(4), 47-492.

Price, M., Handley, K., Millar, J., \& O'Donovan, B. (20I0). Feedback: All that effort, but what is the effect? Assessment \& Evaluation in Higher Education, 35(3), 277-289.

Pryor, J., \& Crossouard, B. (2010). Challenging formative assessment: Disciplinary spaces and identities. Assessment \& Evaluation in Higher Education, 35(3), 265-276.

Rowe, A. (20II). The personal dimension in teaching: why students value feedback. International Journal of Educational Management, 25(4), 343-360. https://doi.org/l0.1108/095/3541।III36630

Rowe, A. (2017). Feelings about feedback: The role of emotions in assessment for learning. In D. Carless, S. Bridges, C. Chan, \& R. Glofcheski (Eds.), Scaling up Assessment for Learning in Higher Education. The enabling Power of Assessment 5 (pp. 159-172). Springer.

Rushton, A. (2005). Formative assessment: A key to deep learning? Medical Teacher, 27(6), 509-5I3.

Sadler, I., \& Reimann, N. (2018). Variation in the development of teachers' understandings of assessment and their assessment practices in higher education. Higher Education Research \& Development, 37(I), I31-144. https://doi.org//0.1080/0729436 0.2017 .1344199

Sadler, R. (2010). Beyond feedback: Developing student capability in complex appraisal. Assessment \& Evaluation in Higher Education, 35(5), 535-550.

Senye-Mir, A., Arumí-Prat, J., Pla-Campas, G., \& Ramírez, E. (2016). Effects of formative assessment on the learning-to-learn skills of teacher training students. Procedia - Social and Behavioral Sciences, 228, 196-201.

Schuwirth, L. W. T., \& Van der Vleuten, C. P. M. (20II). Programmatic assessment: From assessment of learning to assessment for learning. Medical Teacher, 33(6), 478-485. https://doi.org/10.3109/0142159X.2011.565828

Tang, C. S., \& Biggs, J. B. (2007). Teaching for quality learning at university: what the student does. (3rd ed.) McGraw-Hill/Society for Research into Higher Education.

Taras, M. (2005). Assessment - summative and formative - some theoretical reflections. British Journal of Educational Studies, 53(4), 466-478. https://doi.org//0.11/1/j.1467-8527.2005.00307.x

Taylor, C., \& Burke da Silva, K. (2014). An analysis of the effectiveness of feedback to students on assessment work. Higher Education Research \& Development, 33(4), 794-806. https://doi.org/l0.1080/07294360.2013.863840

Weurlander, M., Söderberg, M., Scheja, M., Hult, H., \& Wernerson, A. (20I2). Exploring formative assessment as a tool for learning: Students' experiences of different methods of formative assessment. Assessment \& Evaluation in Higher Education, 37(6), 747-760.

Wiliam, D. (20II). Embedded formative assessment. Solution Tree Press.

Wiliam, D. (2011). What is assessment for learning? Studies in Educational Evaluation, 37(I), 3-14.

Winstone, N., \& Boud, D. (2019). Exploring cultures of feedback practice: The adoption of learning-focussed feedback practices in the UK and Australia. Higher Education Research \& Development, 38(2), 4II-425. https://doi.org/I0.I080/07294360.20 18.1532985

Yorke, M. (2003). Formative assessment in higher education: Moves towards theory and the enhancement of pedagogic practice. Higher Education, 45(4), 477-50I. 